\title{
New records of polychaetes (Annelida: Polychaeta) from three locations of Oaxaca, Mexico
}

\section{Yessica Chávez-López ${ }^{1} \&$ Christopher Cruz-Gómez²}

1. Laboratorio de Sistemática de Invertebrados Marinos (LABSIM), Universidad del Mar, Puerto Ángel, Oaxaca, 70902, México; yess.ch105@gmail.com

2. Posgrado en Ciencias en Recursos Naturales y Desarrollo Rural, El Colegio de la Frontera Sur (ECOSUR), Unidad Chetumal, Chetumal, Quintana Roo, 77014, México; christopher.cruz-gomez@hotmail.com

\author{
Recibido 03-XII-2018. Corregido 25-V-2019. Accepted 30-VI-2019.
}

\begin{abstract}
Introduction: The knowledge of polychaetes from Oaxaca, Mexico, is represented by 41 families and 241 species, nevertheless, 148 species are considered questionable. The majority of taxonomic studies of polychaetes in Oaxaca have taken placed on estuarine zones or commercial ports, sidelining other marine ecosystems. Objective: To identify the polychaeta-fauna from three different marine ecosystems in Oaxaca, Mexico. Methods: Specimens analyzed came from the Sección de poliquetos de la Colección Científica at the Laboratorio de Sistemática de Invertebrados Marinos, Universidad del Mar. The material deposited in the collection was collected between 2007-2017; additionally, new collect were realized in 2017. For each locality, the family and species richness were estimated using the accumulation function of linear dependence model. Results: One hundred lots and 273 specimens were revised. Seventy-one taxa, belonging to 47 genera and 21 families were identified, only twenty of these taxa are confirmed species (28\%). Chacahua Lagoon had the highest richness and relative abundance with 37 taxa and 149 specimens, Agua Blanca was identified 21 taxa and 92 specimens, and from San Agustín 19 taxa and 32 specimens. Sabellariidae had the highest relative abundance (58 specimens), while Phyllodocidae presented the highest species richness (12 species). Conclusions: This study adds 75 new records of taxa of polychaetes to the coast Oaxaca, which increase the knowledge in this animal group, now represented by 304 species, belonging to 154 genera and 42 families.
\end{abstract}

Key words: Agua Blanca, Chacahua Lagoon, checklist, San Agustín, marine worms, southern Mexican Pacific.

Chávez-López, Y., \& Cruz-Gómez, C. (2019). New records of polychaetes (Annelida: Polychaeta) from three locations of Oaxaca, Mexico. Revista de Biología Tropical, 67(S5) Suplemento, S157-S168.

The State of Oaxaca is considered among the top three of the states with highest biodiversity in Mexico (López-Pérez et al., 2012; Llorrente-Bousquets \& Ocegueda, 2008); nevertheless, richness, distribution and conservation status of many species, including polychaetes, remain poorly known (LópezPérez et al., 2012). The knowledge of the Polychaeta from Oaxaca has been compiled by Bastida-Zavala et al. (2013); they made an historical review of all the records of polychaetes from the coast of Oaxaca, from 1919 to 2011, listing 222 species, however, many of these records (at least $62.92 \%$ ) are questionable.

Nowadays, there are new records of polychaetes, and the polychaeta-fauna from Oaxaca is represented by 241 species (i.e. Tovar-Hernández \& Carrera-Parra, 2011; Salazar-Vallejo, 2012; Bastida-Zavala et al., 
2013; Granja-Fernández, Hernández-Moreno \& Bastida-Zavala, 2013; Salazar-Silva, 2013; Salazar-Silva \& Carrera-Parra, 2014; BastidaZavala, Rodríguez Buelna, de León-González, Camacho-Cruz \& Carmona, 2016; Cruz-Gómez \& Bastida-Zavala, 2018). These records constitute only $1.6 \%$ of the polychaetes known worldwide ( $\sim 15000$ species) and $16.2 \%$ of the polychaetes recorded for Mexican waters (1 500 species, fide Tovar-Hernández, Salazar-Silva, de León-González, Carrera-Parra \& Salazar-Vallejo, 2014).

Even though, many of these works are monographic studies including many sites along the coast of Oaxaca, only seven include poorly studied locations, with varying ecosystems, such as: Chacahua Lagoon (coastal lagoon), Agua Blanca (intertidal rocky shore) and San Agustín (coral reef) (Hartman, 1944, 1950, 1961; Ruiz-Cancino, Carrera-Parra \& Bastida-Zavala, 2011; Salazar-Vallejo, 2012; Bastida-Zavala et al., 2016; Cruz-Gómez \& Bastida-Zavala, 2018). Furthermore, some of the studies of these locations have focused on three families only, Eunicidae (Ruiz-Cancino et al., 2011), Serpulidae (Bastida-Zavala et al., 2016) and Chrysopetalidae (Cruz-Gómez \& Bastida-Zavala, 2018), giving a total of 20 species recorded. Thus, a study of the polychaetes in these locations is necessary to improve our knowledge of the group.

The aim of this study was to identify the polychaetes from three different marine ecosystems from Oaxaca, Mexico. A checklist of polychaetes species recorded from Chacahua Lagoon, Agua Blanca and San Agustín, is included.

\section{MATERIALS AND METHODS}

Specimens analyzed came from the Sección de poliquetos de la Colección Científica (OAX-CC-249-11) at the Laboratorio de Sistemática de Invertebrados Marinos (LABSIM), Universidad del Mar (Puerto Ángel, Oaxaca, Mexico). This material was collected between 2007-2017 from three locations in Oaxaca, Mexican Pacific. Chacahua Lagoon $\left(15^{\circ} 57^{\prime} 57^{\prime \prime} \mathrm{N}-97^{\circ} 40^{\prime} 38^{\prime \prime} \mathrm{W}\right)$, a coastal lagoon belonging to Lagunas de Chacahua National Park; Agua Blanca (154' $58^{\prime \prime} \mathrm{N}-96^{\circ} 48^{\prime} 50^{\prime}$ ' W), an intertidal rocky shore; and San Agustín $\left(15^{\circ} 41^{\prime} 09^{\prime \prime} \mathrm{N}-96^{\circ} 14^{\prime} 05^{\prime \prime} \mathrm{W}\right)$, a bay with a wide area of coral reef.

Specimens were fixed in $10 \%$ formalin solution and preserved in $70 \%$ ethanol solution. In contrast, the material collected in 2017 (obtained through snorkeling in the intertidal zone to $3 \mathrm{~m}$ depth), was fixed and preserved in $96 \%$ ethanol solution. The new specimens collected and all of the material examined was separated in glass vessels and labeled, and deposited in the Sección de poliquetos of LABSIM.

The identification of the polychaetes was made using the keys of de León-González et al. (2009); it was also corroborated with specialized literature for each family. The checklist is shown in alphabetical order.

Family and species richness by location was obtained using the accumulation function of linear dependence model (Moreno, 2001). The expected richness was estimated as the number of families or species, considering the sampling effort as number of sampling event for locality. The analyses were performed with EstimateS 9 (Colwell, 2013) and Statistica 8.0 (StatSoft, 2007) software.

To avoid an overestimation of the values of richness, damaged polychaetes, juveniles or specimens with a non-defined taxonomic status were removed prior to the analysis.

\section{RESULTS}

A total 100 lots and 271 specimens were revised. Seventy one taxa belonging to 47 genera and 21 families were recorded (Table 1). Among these records, 20 are confirmed species (28\%), 19 are close to nominal species due to present morphological peculiarities or type locality distant from Oaxaca (27 \%), 14 have unclear systematic status since are incomplete, damaged or juvenile specimens (20\%), and 18 are possible new species $(25 \%)$ which will be formally described by the authors in upcoming 


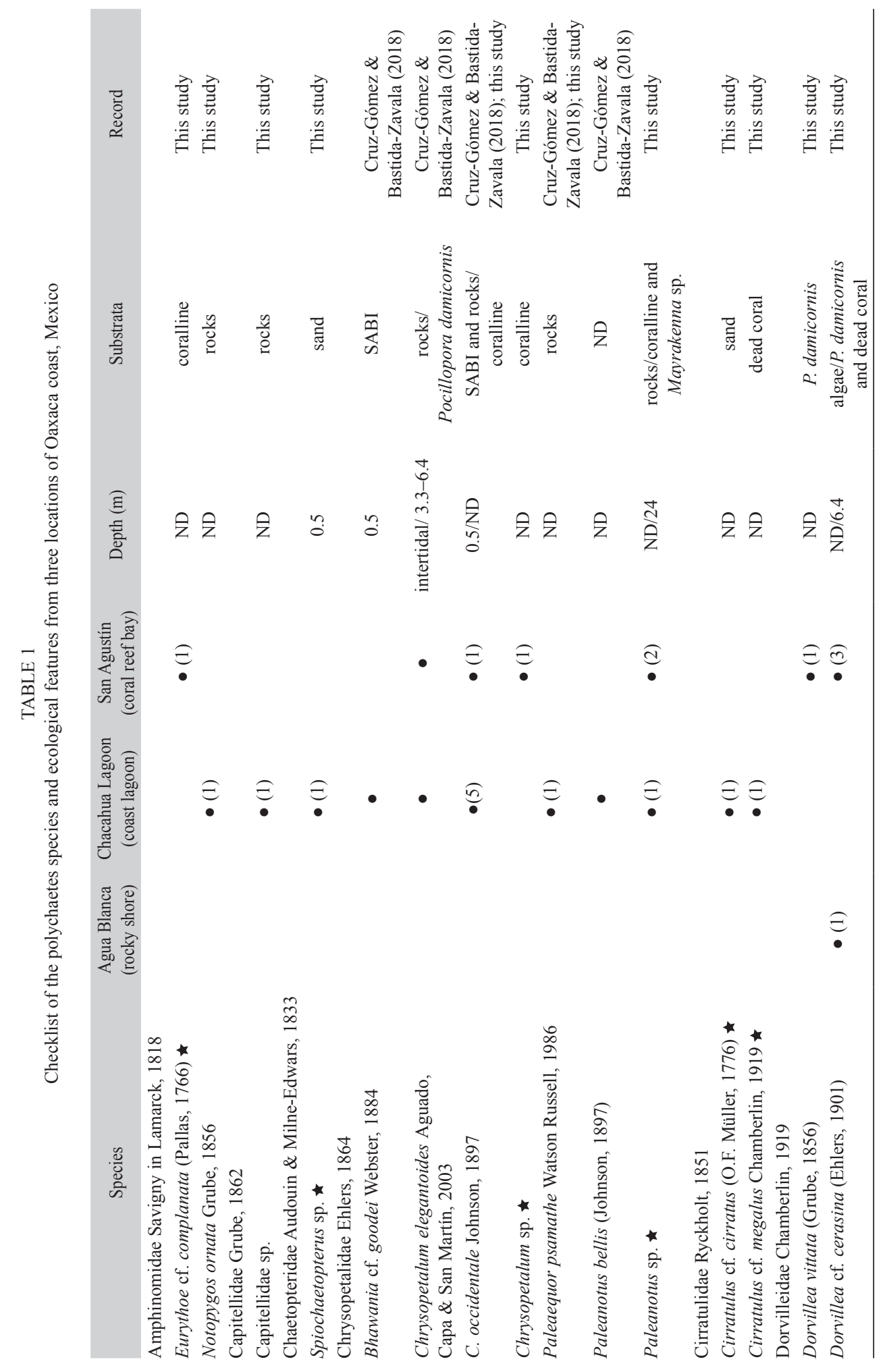

(c) (i) Rev. Biol. Trop. (Int. J. Trop. Biol. ISSN-0034-7744) Vol. 67(S5) Supplement: S157-S168, July 2019 


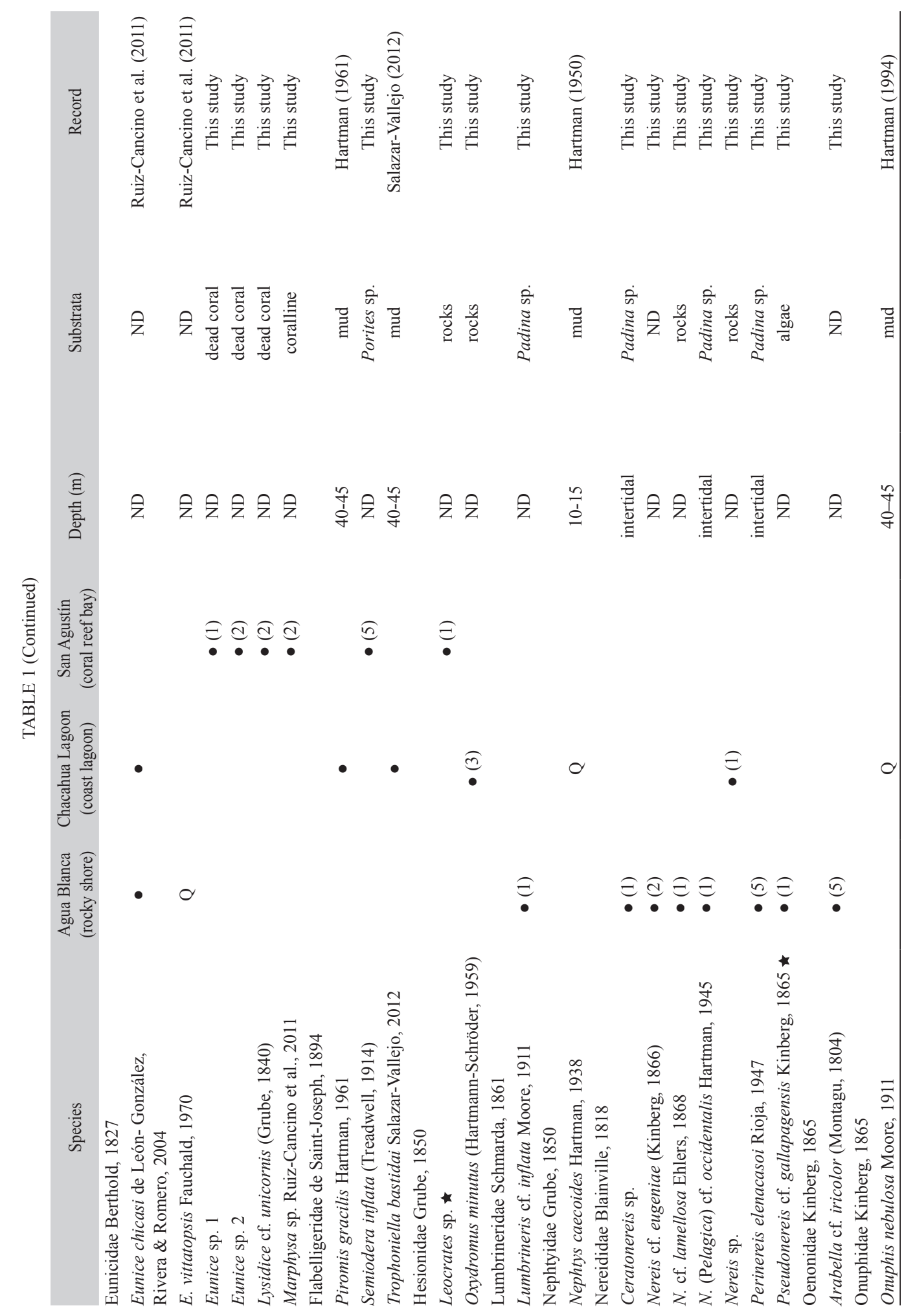




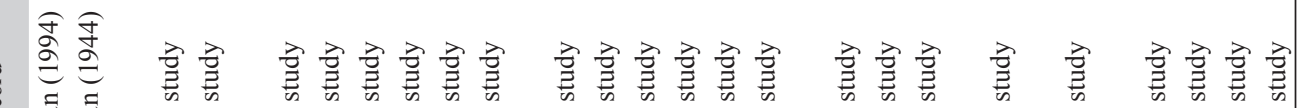

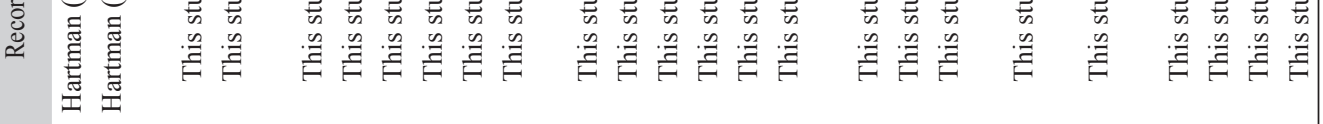

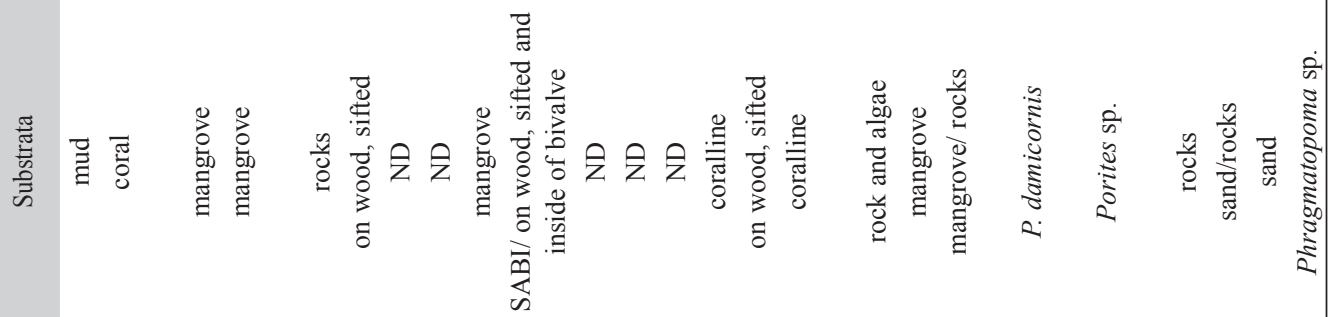

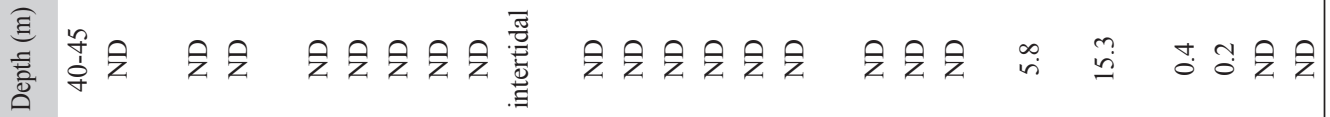

苍

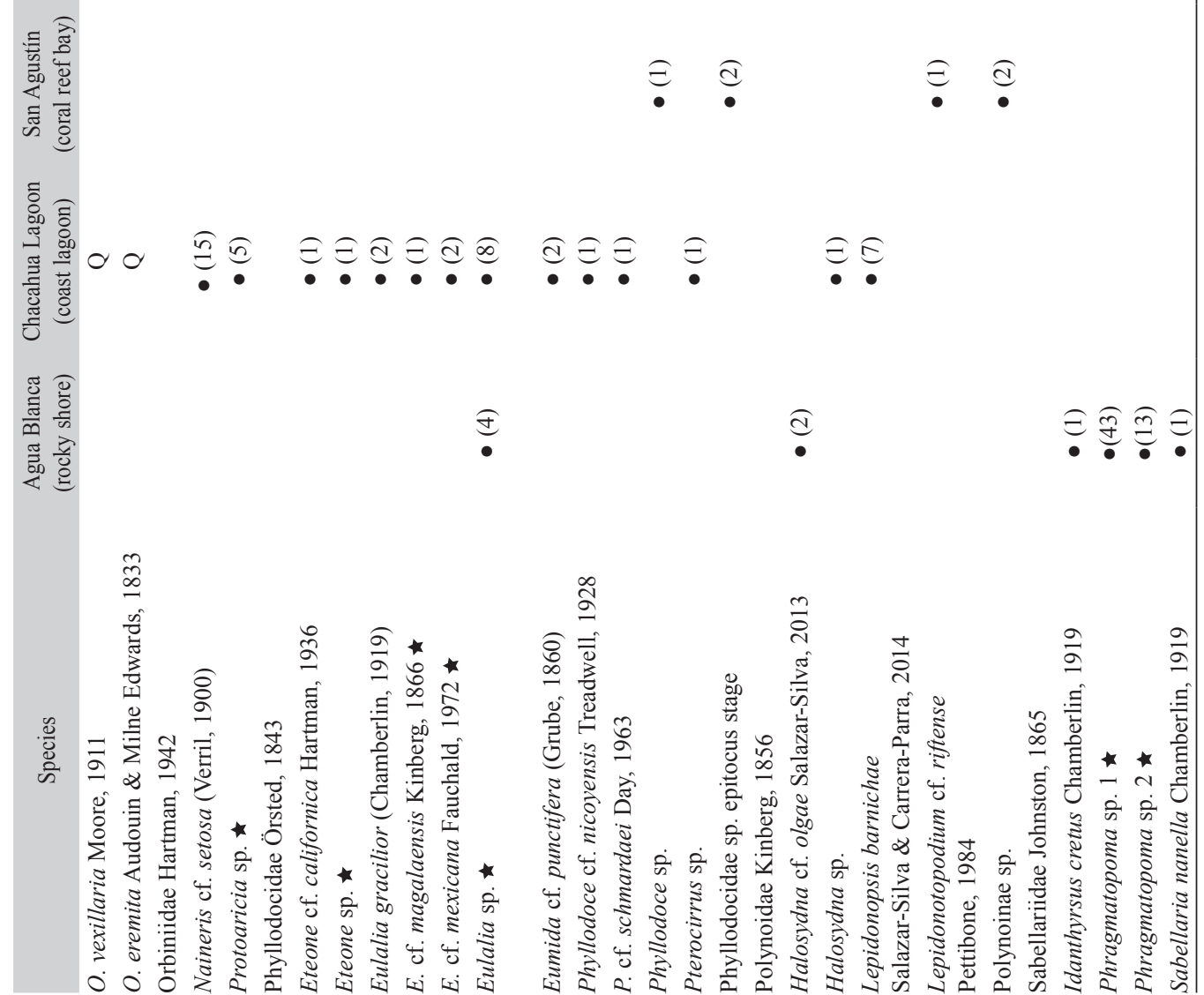




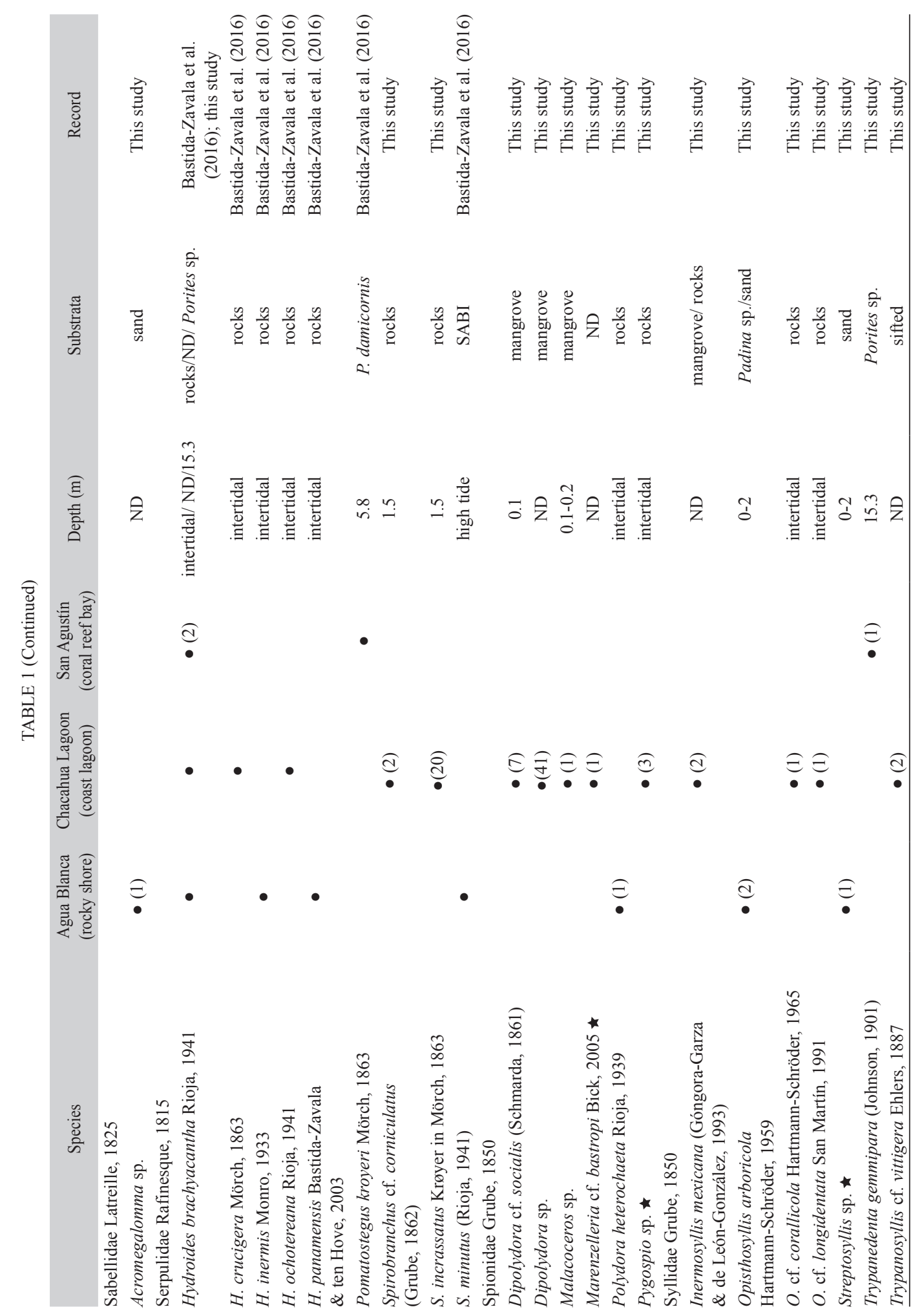




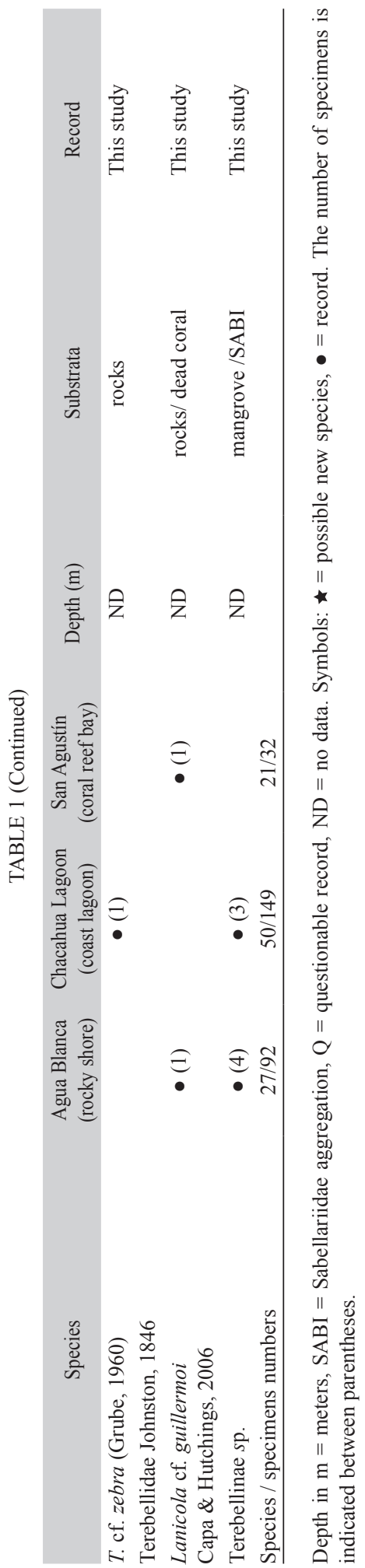

papers. One family (Chaetopteridae), 18 genera and 37 species are new records for the coast of Oaxaca. Twenty-six species are new records for the Mexican Pacific.

In general, Sabellaridae presented the highest abundance with 58 specimens (Fig. 1A, Fig. $2 \mathrm{E}-\mathrm{F}$ ), perhaps due to the fact that its members are gregarious polychaetes. Phyllodocidae was the richest family with 12 species, followed by Syllidae with eight, Nereididae with seven and Spionidae with six species.

As results for each site, Chacahua Lagoon had the highest richness and abundance with 37 taxa and 149 specimens. In Agua Blanca 21 taxa and 92 specimens were identified, and from San Agustín, 19 taxa and 32 specimens. Nereididae was the family with highest richness (six species) in Agua Blanca, whereas Sabellariidae presented the highest relative abundance (58 specimens) (Fig. 1A). In Chacahua Lagoon, Phyllodocidae was the richest family (10 species) and Spionidae had the highest abundance (53 specimens) (Fig. 1B). In San Agustín, Eunicidae had the highest richness and abundance (four species, seven specimens) (Fig. 1C). Lumbrineridae, Chaetopteridae, Capitellidae and Sabellidae had the lowest abundance in these locations, with only one specimen each one.

To avoid an overestimation of the values of the richness, the only specimens removed were Terebellinae sp. in Agua Blanca and Phyllodocidae sp. epitocus stage in San Agustín, since these could be duplicate data (Lanicola cf. carus and Phyllodoce sp., respectively). With the accumulation function, the expected richness was 14 families $\left(\mathrm{R}=0.999, \mathrm{R}^{2}=99.998\right.$ $\%$, asymptote $=13.92, \mathrm{~b}=0.141)$ and 44 species for Agua Blanca $\left(\mathrm{R}=1.000, \mathrm{R}^{2}=100 \%\right.$, asymptote $=43.71, \mathrm{~b}=0.055), 18$ families $(\mathrm{R}$ $=0.999, \mathrm{R}^{2}=99.964 \%$, asymptote $=17.93$, $\mathrm{b}=0.239)$ and 70 species for San Agustín ( $=1.000, \mathrm{R}^{2}=100 \%$, asymptote $=70.32, \mathrm{~b}=$ $0.073)$, and 23 families $\left(\mathrm{R}=0.999, \mathrm{R}^{2}=99.926\right.$ $\%$, asymptote $=22.71, \mathrm{~b}=0.0 .085)$ and 165 species for Chacahua Lagoon $\left(\mathrm{R}=1.000, \mathrm{R}^{2}=\right.$ $100 \%$, asymptote $=164.50, \mathrm{~b}=0.023)$. 
A

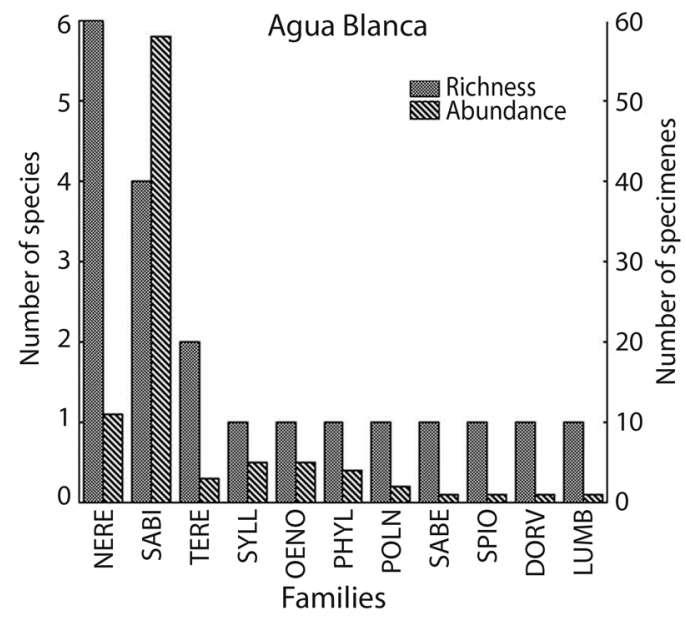

C

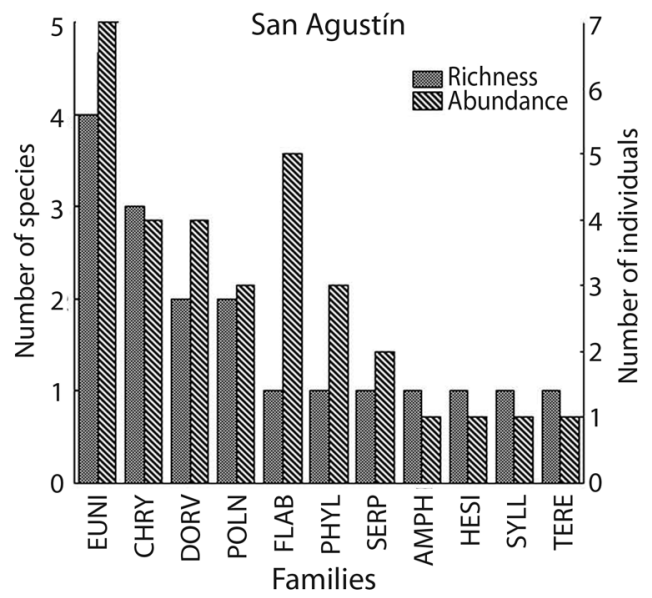

B

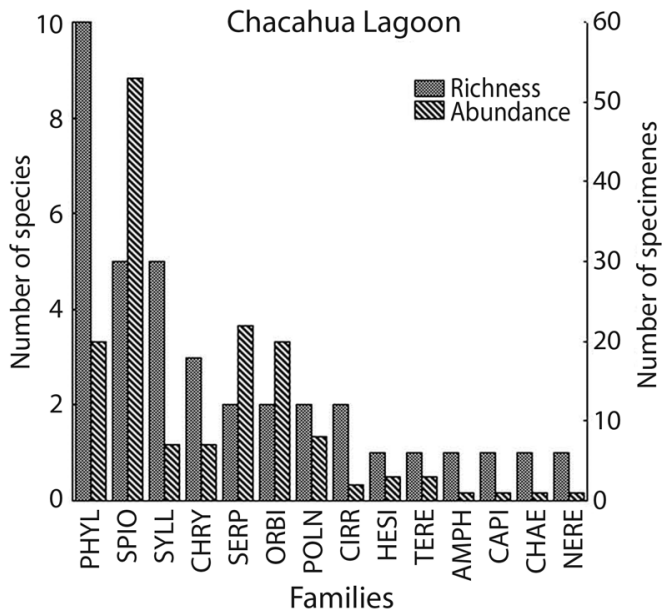

D

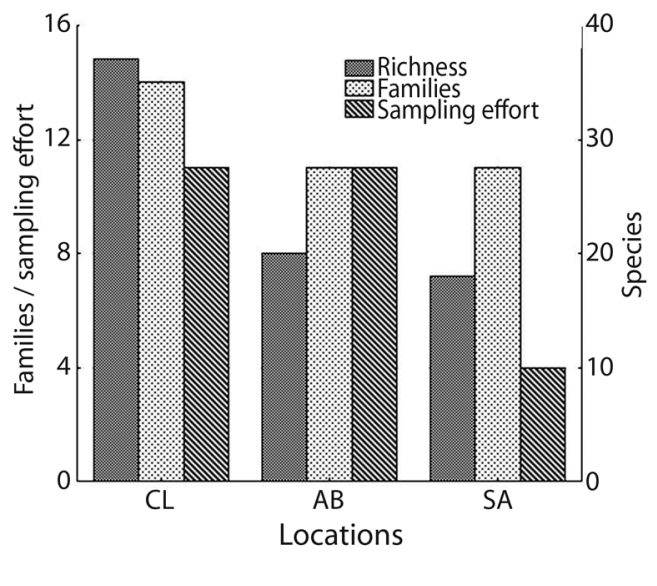

Fig. 1. Abundance and richness of polychaetes from (A) Agua Blanca; (B) Chacahua Lagoon; (C) San Agustín. (D) Comparison between locations. The short names of the Polychaeta families are following Salazar-Vallejo, de León-González \& Saláices-Polanco (1988).

\section{DISCUSSION}

In the Mexican Pacific, some studies has incremented the polychaetes knowledge from particular ecosystems such as rocky and sandy zone in La Paz, Baja California Sur (BastidaZavala, 1993), coralline zone in Cabo Pulmo, Baja California Sur (Bastida-Zavala, 1995), buoys zone in Mazatlán, Sinaloa (Villalobos-Guerrero \& Tovar-Hernández, 2014), and coralline and rocky zone in Huatulco-Puerto Angel, Oaxaca (Gómez, Mercado, Mitchell, \& Salazar-Vallejo, 1997).
In Oaxaca, before this study, there were only 20 recorded species of polychaetes from Chacahua Lagoon, Agua Blanca, and San Agustín (Hartman, 1944, 1950, 1961; RuizCancino et al., 2011; Salazar-Vallejo, 2012; Cruz-Gómez \& Bastida-Zavala, 2018). With this work, this has increased to 71 species, and 75 new records were added: 21 in Agua Blanca, 19 in San Agustín and 35 in Chacahua Lagoon.

Particularly, the study by Gómez et al. (1997) found the highest values of richness (36 species) in coralline zone of La Entrega, Oaxaca. In contrast, among the three locations 


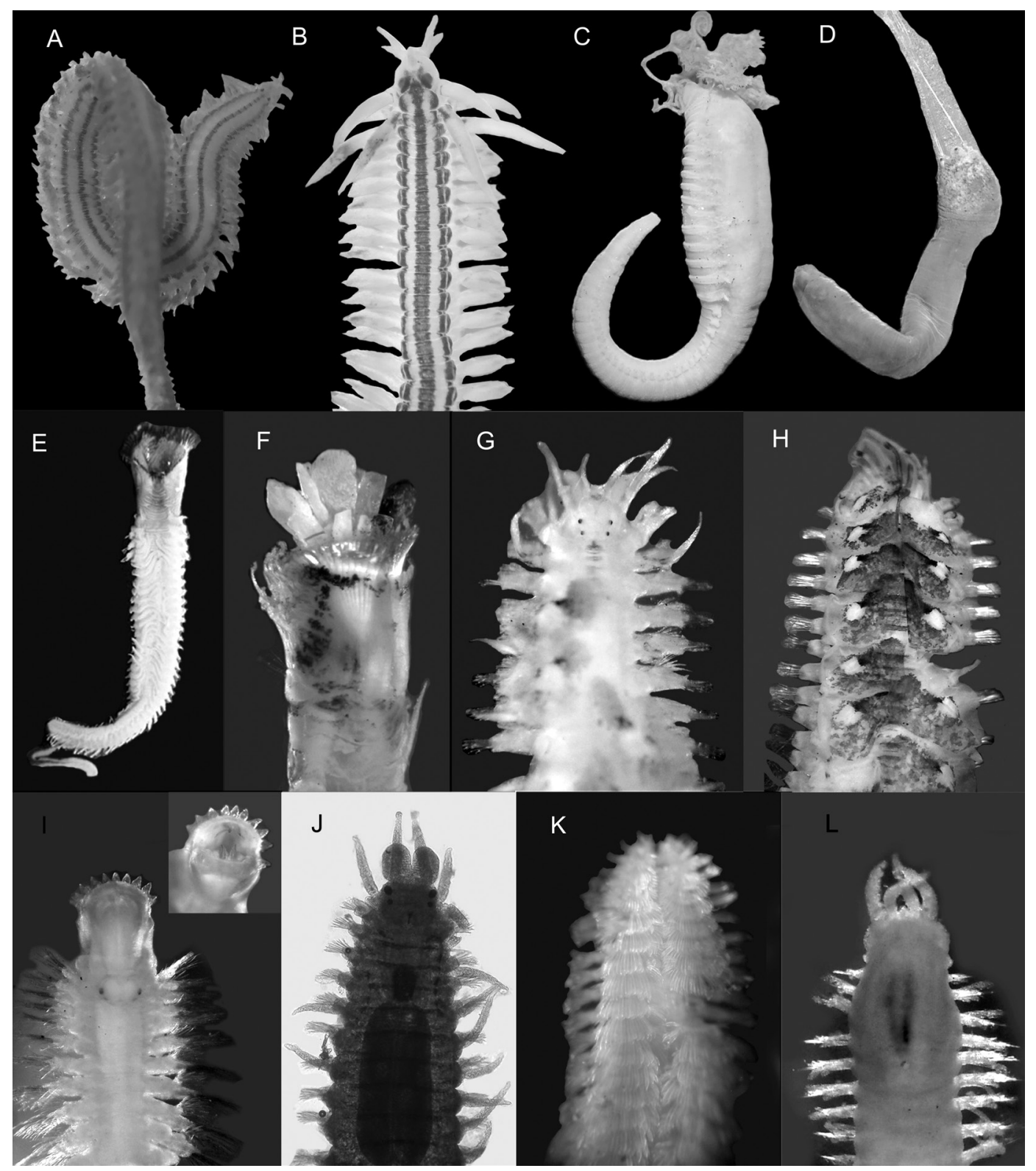

Fig. 2. Examples of the species identified (A) Eulalia gracicolor (B) Eulalia sp. (C) Lanicola cf. guillermoi (D) Semiodera inflata (E) Idanthyrsus cretus (F) Sabellaria nanella (G) Lepidonopsis barnichae (H) Halosydna cf. olgae (I) Lepidonotopodium cf. riftense (J) Streptosyllis sp. (K) Chrysopetalum occidentale (L) Dorvillea vittata.

of study, the highest values of abundance (149 specimens) and richness (37 species) were found in Chacahua Lagoon; this might be due to the diversity of microhabitats studied in this locality: rocky zone, mangrove, sand and muddy zone. On the other hand, the coralline zone of San Agustín showed the lowest abundance (32 specimens) and richness (19 species); however, this location also presented the lowest sampling effort (Fig. 1D).

The Polychaeta-fauna in Chacahua Lagoon, Agua Blanca and San Agustín only 
match in $9 \%$ of their composition, which are six families and eight taxa (Chrysopetalum elegantoides, $C$. occidentale, Paleaonotus sp., Dorvillea cf. cerasina, Eunice chicasi, Eulalia sp., Hydroides brachyacantha, and Lanicola cf. guillermoi). This indicates that these three locations present particular environmental conditions with different types of marine biota. On the other hand, the results of this work coincide with Gómez et al. (1997) in the presence of $C$. occidentale, Idanthyrsus cretus, $H$. brachyacantha, $H$. crucigera, and Spirobranchus incrassatus in the Oaxaca coast. The results also coincides with Bastida-Zavala (1993) in the record of Dorvillea vittata and with Bastida-Zavala (1995) in the record of Perinereis elenecasoi, but also these studies recorded many questionable species, to avoid questionable records here were referred this kind of species as confer (e.g. Bhawania cf. godei). The study by Villalobos-Guerrero and Tovar-Hernández (2014) coincides with our study in the presence of Dorvillea vittata, Eunice sp. 2, Marphysa sp., Perinereis elenacasoi and Eulalia gracicolor.

Considering the results obtained, to date the Polychaeta-fauna from Oaxaca is represented by 304 species, belonging to 154 genera and 42 families. Comparatively, the Polychaeta from the coast of Oaxaca are better known than other states, such as Chiapas (five species) and Michoacán (57 species) (Bastida-Zavala \& García-Madrigal, 1998; Bastida-Zavala \& García-Madrigal, 2012; Bastida-Zavala \& Guevara-Cruz, 2012); however, the species richness of polychaetes from Oaxaca still less known than other states as Sinaloa with 464 species recorded (Villalobos-Guerrero \& Molina-Acevedo, 2014). The number of species and records of the polychaetes in the Mexican south Pacific could increase if intensify and explore new locations and other habitats (e.g. sandy beaches, deep reefs, submarine canyons, mixohaline lagoons).

Ethical statement: authors declare that they all agree with this publication and made significant contributions; that there is no conflict of interest of any kind; and that we followed all pertinent ethical and legal procedures and requirements. All financial sources are fully and clearly stated in the acknowledgements section. A signed document has been filed in the journal archives.

\section{ACKNOWLEDGMENTS}

We thank Juan Pablo Sánchez-Ovando (LABSIM-UMAR, Puerto Ángel) for his help with serpulid and spionid identification. Thanks are also extended to Rolando Bastida-Zavala, Karla J. Humara-Gil (LABSIM-UMAR, Puerto Ángel), Gerardo FloresTaboada (ECOSUR, Chetumal) and the two anonymous reviewers for their valuable comments on the manuscript. This work was supported by the Mexican Network of Exotic Species (UMAR-UANL-UABC), with funds of PRODEP (103-5/09/1353).

\section{RESUMEN}

\section{Nuevos registros de poliquetos (Annelida: Polychaeta) de tres localidades de Oaxaca, México}

Introducción: El conocimiento de poliquetos en Oaxaca, México, está representado por 41 familias y 241 especies, sin embargo, 148 especies son consideradas cuestionables. La mayoría de los estudios taxonómicos de poliquetos en Oaxaca se han enfocado en zonas estuarinas o puertos comerciales, dejando de lado otros ecosistemas marinos. Objetivo: Identificar la poliqueto-fauna de tres ecosistemas diferentes de Oaxaca. Métodos: Los especímenes analizados pertenecen a la Sección de poliquetos de la Colección Científica del Laboratorio de Sistemática de Invertebrados Marinos, Universidad del Mar. El material depositado en la colección fue colectado entre 2007-2017; adicionalmente, se realizaron nuevas colectas en 2017. Para cada localidad, la riqueza de especies y familias fue estimada utilizando la función de acumulación del modelo de dependencia lineal. Resultados: Se revisaron 100 lotes y 273 especímenes. Se identificaron 71 taxones, pertenecientes a 47 géneros y 21 familias, solo 20 de estos taxones corresponden a nombres específicos (28\%). La Laguna de Chacahua presentó la mayor riqueza y abundancia relativa con 37 taxones y 149 especímenes, en Agua Blanca se identificaron 21 taxones y 92 especímenes, y para San Agustín 19 taxones y 32 especímenes. La familia Sabellariidae tuvo la mayor abundancia relativa (58 especímenes), mientras que Phyllodocidae presentó la mayor riqueza de 
especies (12 especies). Conclusiones: Con este estudio se añaden 75 nuevos registros de poliquetos para la costa de Oaxaca, incrementando el conocimiento de este grupo, ahora representado por 304 especies pertenecientes a 154 géneros y 42 familias.

Palabras clave: Agua Blanca, laguna de Chacahua, listado de especies, San Agustín, gusanos marinos, Pacífico sur de México.

\section{REFERENCES}

Bastida-Zavala, J. R. (1993). Taxonomía y composición biogeográfica de los poliquetos (Annelida: Polychaeta) de la bahía de La Paz, B.C.S., México. Revista de Investigación Científica, 4(1), 11-39.

Bastida-Zavala, J. R. (1995). Poliquetos (Annelida: Polychaeta) del arrecife coralino de Cabo Pulmo-Los Frailes, B.C.S., México. Revista de Zoología, 6, 9-29.

Bastida-Zavala, J. R., \& García-Madrigal, M. S. (1998). Lista de poliquetos (Annelida: Polychaeta) y braquiuros (Crustacea: Decápoda) registrados para la costa de Michoacán, México. Quetzal, 8, 21-25.

Bastida-Zavala, J. R., \& García-Madrigal, M. S. (2012). First record in the Tropical Eastern Pacific of the exotic species Ficopomatus uschavoki (Polychaeta, Serpulidae). ZooKeys, 238, 45-55.

Bastida-Zavala, J. R., García-Madrigal, M. S., RosasAlquicira, E. F., López-Pérez, R. A., Benítez-Villalobos, F., Meraz-Hernando, J. F., ... Barrientos-Luján, N. A. (2013). Marine and coastal biodiversity of Oaxaca, Mexico. Check List, 9(2), 329-290.

Bastida-Zavala, J. R., \& Guevara-Cruz, C. (2012). Estado del conocimiento de los poliquetos (Annelida: Polychaeta) del Pacífico sur de México. In A. J. Sánchez, X. Chiappa-Carrara \& R. Brito-Pérez (Eds.), Recursos Acuáticos Costeros del Sureste (pp. 335355, Vol. 1). Mérida, Yucatán: Red para el Conocimiento de los Recursos Costeros de México Press.

Bastida-Zavala, J. R., Rodríguez Buelna, A. S., de LeónGonzález, J. A., Camacho-Cruz, K. A., \& Carmona, I. (2016). New records of sabellids and serpulids (Polychaeta: Sabellidae, Serpulidae) from the Tropical Eastern Pacific. Zootaxa, 484(3), 401-457.

Colwell, R. K. (2013). EstimateS: Statistical estimation of species richness and shared species from samples. Version 9. User's Guide ad application. Retrieved from http://purl.oclc.org/estimates

Cruz-Gómez, C., \& Bastida-Zavala, J. R. (2018). Chrysopetalids (Phyllodocida: Chrysopetalidae) from the southern Mexican Pacific, including a new species. Zootaxa, 4521(1), 61-88. de León-González, J. A., Bastida-Zavala, J. R., CarreraParra, L. F., García-Garza, M. E., Peña-Rivera, A., Salazar-Vallejo, S. I., \& Solís-Weiss, V. (2009). Poliquetos (Annelida: Polychaeta) de México y América Tropical. Nuevo León, México: Universidad Autónoma de Nuevo León.

Granja-Fernández, R., Hernández-Moreno, P., \& BastidaZavala, J. R. (2013). First record of the association between Malmgriella $\mathrm{cf}$. variegata (Polychaeta, Polynoidae) and Ophionereis annulata (Echinodermata, Ophionereididae) in the Mexican Pacific. Symbiosis, 60, 85-90.

Gómez, P., Mercado, J. A., Mitchell, L. M., \& SalazarVallejo, S. I. (1997). Poliquetos de fondos duros (Polychaeta) de bahías de Huatulco y Puerto Ángel, Oaxaca, México. Revista de Biología Tropical, 45(3), 1067-1074.

Hartman, O. (1944). Polychaetous annelids Part V. Eunicea. Allan Hancock Pacific Expedition, 10(1), 1-236.

Hartman, O. (1950). Polychaetous annelids. Goniadidae, Glyceridae and Nephtyidae. Allan Hancock Pacific Expedition, 15(1), 1-181.

Hartman, O. (1961). Polychaetous annelids from California. Allan Hancock Pacific Expedition, 25(1), 1-226.

Llorente-Bousquets, J., \& Ocegueda, S. (2008). Estado del conocimiento de la biota, en Capital natural de México, vol. I: Conocimiento actual de la biodiversidad. Ciudad de México, México: Conabio.

López-Pérez, R. A., Bastida-Zavala, J. R., García-Madrigal, M. S., Barrientos-Luján, N. A., Torres-Huerta, A. M., Montoya-Márquez, J. A., ... Meráz-Hernando, J. F. (2012). ¿Cuánto sabemos de la diversidad de la fauna marina y costera de Oaxaca?. In A. J. Sánchez, X. Chiappa-Carrara \& R. Brito-Pérez (Eds.). Recursos Acuáticos Costeros del Sureste (pp. 435-449, Vol. 1). Mérida, Yucatán: Red para el Conocimiento de los Recursos Costeros de México Press.

Moreno, C. E. (2001). Métodos para medir la biodiversidad (Vol. 1). Zaragoza, España: M\&T-Manuales y Tesis SEA.

Ruiz-Cancino, G., Carrera-Parra, L. F., \& Bastida-Zavala, J. R. (2011). Eunícidos (Polychaeta: Eunicidae) del Pacífico sur de México. Ciencia y Mar, 14(40), 27-60.

Salazar-Silva, P. (2013). Revision of Halosydna Kinberg, (Annelida: Polychaeta: Polynoidae) from the Tropical Eastern Pacific and Grand Caribbean with descriptions of new species. Journal of Natural History, 47, 1177-1242.

Salazar-Silva, P., \& Carrera-Parra, L. F. (2014). Revision of Lepidonopsis humilis (Augener, 1922) and description L. barnichae sp. nov. (Annelida: Polychaeta: 
Polynoidae) based upon morphological and molecular characters. Zootaxa, 3790(4), 555-566.

Salazar-Vallejo, S. I. (2012). Revision of Trophoniella Hartman, 1959 (Polychaeta, Flabelligeridae). Zoosystema, 34(3), 453-519.

Salazar-Vallejo, S. I., de Léon-González, A., \& SaláicesPolanco, H. (1988). Poliquetos (Annelida: Polychaeta) de México. La Paz, México: Libros Universitarios, UABCS.

StatSoft, Inc. (2007). STATISTICA (data analysis software system). Version 8.0. Retrieved from http://www. statsoft.com/Products/STATISTICA-Features

Tovar-Hernández, T., \& Carrera-Parra, L. F. (2011). Megalomma Johansson, 1925 (Polychaeta: Sabellidae) from America and other world-wide localities, and phylogenetic relationships within the genus. Zootaxa, $2861,1-71$

Tovar-Hernández, M. A., Salazar-Silva, P., de León-González, J. A., Carrera-Parra, L. F., \& Salazar-Vallejo, S. I. (2014). Biodiversity of Polychaeta (Annelida) in Mexico. Revista Mexicana de Biodiversidad, 85, 190-196.

Villalobos-Guerrero, T. F., \& Molina-Acevedo, I. C. (2014). Lista de especies y estado de conocimiento de los poliquetos (Annelida: Polychaeta) de Sinaloa, Golfo de California. Boletín del Instituto Oceanográfico de Venezuela, 53(1), 79-109.

Villalobos-Guerrero, T. F., \& Tovar-Hernández, M. A. (2014). Poliquetos errantes (Polychaeta: Errantia) esclerobiontes del puerto de Mazatlán, Sinaloa (México). Boletín de Investigaciones Marinas y Costeras, 43(1), 43-87. 